Research article

\title{
Epidemiology of breast cancer subtypes in two prospective cohort studies of breast cancer survivors
}

\author{
Marilyn L Kwan ${ }^{1}$, Lawrence H Kushi ${ }^{1}$, Erin Weltzien ${ }^{1}$, Benjamin Maring ${ }^{1}$, Susan E Kutner ${ }^{2}$, \\ Regan S Fulton ${ }^{3}$, Marion M Lee ${ }^{4}$, Christine B Ambrosone ${ }^{5}$ and Bette J Caan ${ }^{1}$
}

\author{
${ }^{1}$ Kaiser Permanente, Division of Research, 2000 Broadway, First Floor, Oakland, CA 94612, USA \\ 2Kaiser Permanente, San Jose, 280 Hospital Parkway, San Jose, CA 95119, USA \\ 3Kaiser Permanente, Regional Immunohistochemistry Laboratory, 350 St. Joseph's Street, San Francisco, CA 94115, USA \\ ${ }^{4}$ Department of Epidemiology and Biostatistics, Box 0981, 185 Berry Street 6600, University of California, San Francisco, CA 94143-0981, USA \\ 5Department of Cancer Prevention and Control, Roswell Park Cancer Institute, Elm \& Carlton Streets, Buffalo, NY 14263, USA \\ Corresponding author: Marilyn L Kwan, marilyn.I.kwan@kp.org
}

Received: 6 Jan 2009 Revisions requested: 23 Feb 2009 Revisions received: 23 Mar 2009 Accepted: 22 May 2009 Published: 22 May 2009

Breast Cancer Research 2009, 11:R31 (doi:10.1186/bcr2261)

This article is online at: http://breast-cancer-research.com/content/11/3/R31

(c) 2009 Kwan et al:; licensee BioMed Central Ltd.

This is an open access article distributed under the terms of the Creative Commons Attribution License (http://creativecommons.org/licenses/by/2.0), which permits unrestricted use, distribution, and reproduction in any medium, provided the original work is properly cited.

\begin{abstract}
Introduction The aim of this study was to describe breast tumor subtypes by common breast cancer risk factors and to determine correlates of subtypes using baseline data from two pooled prospective breast cancer studies within a large health maintenance organization.

Methods Tumor data on 2544 invasive breast cancer cases subtyped by estrogen receptor, progesterone receptor, and human epidermal growth factor receptor 2 (Her2) status were obtained (1868 luminal A tumors, 294 luminal B tumors, 288 triple-negative tumors and 94 Her2-overexpressing tumors). Demographic, reproductive and lifestyle information was collected either in person or by mailed questionnaires. Caseonly odds ratios (ORs) and 95\% confidence intervals (Cls) were estimated using logistic regression, adjusting for age at diagnosis, race/ethnicity, and study origin.

Results Compared with luminal A cases, luminal B cases were more likely to be younger at diagnosis $(P=0.0001)$ and were less likely to consume alcohol $(\mathrm{OR}=0.74,95 \% \mathrm{Cl}=0.56$ to $0.98)$, use hormone replacement therapy (HRT) (OR $=0.66$, $95 \% \mathrm{Cl}=0.46$ to 0.94 ), and oral contraceptives (OR $=0.73$,

$95 \% \mathrm{Cl}=0.55$ to 0.96$)$. Compared with luminal A cases, triplenegative cases tended to be younger at diagnosis $(P \leq 0.0001)$ and African American ( $\mathrm{OR}=3.14,95 \% \mathrm{Cl}=2.12$ to 4.16 ), were more likely to have not breastfed if they had parity greater than or equal to three $(\mathrm{OR}=1.68,95 \% \mathrm{Cl}=1.00$ to 2.81$)$, and were more likely to be overweight $(\mathrm{OR}=1.82,95 \% \mathrm{Cl}=1.03$ to 3.24$)$ or obese $(\mathrm{OR}=1.97,95 \% \mathrm{Cl}=1.03$ to 3.77$)$ if premenopausal. Her2-overexpressing cases were more likely to be younger at diagnosis $(P=0.03)$ and Hispanic $(\mathrm{OR}=2.19$, $95 \% \mathrm{Cl}=1.16$ to 4.13 ) or Asian (OR $=2.02,95 \% \mathrm{Cl}=1.05$ to 3.88 ), and less likely to use HRT (OR $=0.45,95 \% \mathrm{Cl}=0.26$ to 0.79 ).

Conclusions These observations suggest that investigators should consider tumor heterogeneity in associations with traditional breast cancer risk factors. Important modifiable lifestyle factors that may be related to the development of a specific tumor subtype, but not all subtypes, include obesity, breastfeeding, and alcohol consumption. Future work that will further categorize triple-negative cases into basal and non-basal tumors may help to elucidate these associations further.
\end{abstract}

\section{Introduction}

Among women in the USA, breast cancer remains the most commonly diagnosed cancer, excluding skin cancers, and the second leading cause of cancer-related death [1]. Breast can- cer is characterized by its molecular and clinical heterogeneity. Studies using cDNA microarrays and immunohistochemical (IHC) markers [2-6] have classified breast cancers into five distinct subtypes: luminal $A$ (estrogen receptor (ER) positive

BMI: body mass index; CBCS: Carolina Breast Cancer Study; Cl: confidence interval; CK: cytokeratin; EGFR: epidermal growth factor receptor; ER: estrogen receptor; FISH: fluorescence in situ hybridization; Her2: human epidermal growth factor receptor 2; HRT: hormone replacement therapy; IHC: immunohistochemical; IRB: institutional review board; KPNC: Kaiser Permanente Northern California; LACE: Life After Cancer Epidemiology; OC: oral contraceptive; OR: odds ratio; PBCS: Polish Breast Cancer Study; PR: progesterone receptor; WS: Washington State. 
and/or progesterone receptor (PR) positive, human epidermal growth factor receptor 2 (Her2) negative), luminal B (ER positive and/or PR positive, Her2 positive), Her2 overexpressing (ER negative, PR negative, Her2 positive), basal-like (ER negative, PR negative, Her2 negative, cytokeratin (CK) 5/6 positive and/or epidermal growth factor receptor (EGFR) positive) and normal breast-like tumors. Approximately $70 \%$ of 'triplenegative' breast cancers (ER negative, PR negative, Her2 negative) express basal markers [7-9], resulting in the triple-negative subtype commonly being used as a surrogate marker for the basal-like subtype.

Luminal tumors have been associated with the most favorable prognoses, while Her2-overexpressing and basal-like tumors, or their surrogate triple negative tumors, have been associated with the worst prognoses $[2,3,5,6,10-18]$. For triple-negative tumors, the peak risk of recurrence occurs within three years of diagnosis, and mortality rates are increased for five years after diagnosis $[14,19]$. The subtype accounts for approximately $15 \%$ of invasive breast cancers $[2,4,10,11,20]$ and is commonly associated with African American race [2,10,17,20-22], younger age at diagnosis $[10,11,14,16,17,19,20,22-24]$, more advanced stage $[10,11,24]$, higher grade $[2,5,9,11,14,16,17,19,21,24,25]$, high mitotic indices $[2,16,26]$, family history of breast cancer [27], and BRCA1 mutations [23,28,29].

Although many studies have examined associations between common breast cancer risk factors, race [30-36] and hormone receptor status [36-41], few studies have explored the relationship between common breast cancer risk factors and the molecular subtypes of breast cancer $[22,27,42,43$ ] [see Additional data file 1]. Therefore, we set out to describe breast tumor subtypes by race/ethnicity and common breast cancer risk factors and to determine correlates of breast cancer subtypes using baseline data from two large, prospective breast cancer survivorship studies of 2544 invasive breast cancer cases.

\section{Materials and methods LACE Study}

The Life After Cancer Epidemiology (LACE) Study consists of 2280 women diagnosed with invasive breast cancer between 1997 and 2000 and recruited primarily from the Kaiser Permanente Northern California (KPNC) Cancer Registry (82\%) and the Utah Cancer Registry (12\%). Further details on the LACE cohort have been previously reported [44]. Briefly, eligibility criteria included age between 18 and 70 years at enrollment; a diagnosis of early-stage primary breast cancer (stages $I \geq 1$ cm, II, or IIIA); enrollment between 11 and 39 months postdiagnosis; having completed breast cancer treatment (except for adjuvant hormonal therapy); free of recurrence; and no history of other cancers in the five years prior to enrollment. Between January 2000 and April 2002, 2280 eligible women completed baseline questionnaires via mail. The mean time from diagnosis to enrollment was 22.8 months (range $=11.0$ to 38.9 months). The study was approved by the institutional review boards (IRB) of KPNC and the University of Utah. The present analysis includes data from $1821 \mathrm{KPNC}$ breast cancer patients from the LACE Study with complete breast cancer subtype information.

\section{Pathways Study}

The Pathways Study is a prospective cohort study actively recruiting women diagnosed with invasive breast cancer from the KPNC patient population since January 2006. Women are recruited as soon after diagnosis as possible (usually within two months), as described elsewhere [45]. Briefly, cases are rapidly ascertained on a daily basis by automatic scanning of electronic pathology reports with subsequent verification of cancer diagnosis and patient notification by a medical record analyst. Eligibility criteria include: current KPNC membership; at least 21 years of age at diagnosis; recent diagnosis of first primary invasive breast cancer (all stages); no prior history of any cancer; ability to speak English, Spanish, Cantonese, or Mandarin; and live within a 65-mile radius of a field interviewer. In addition, a passive consent is obtained from the patient's physician of record by an email notification stating our intention to contact the patient for study recruitment. Recruitment is ongoing, and as of 20 October, 2008, 2212 breast cancer patients have been enrolled via in-person interview. The mean time from diagnosis to enrollment is 1.9 months (range $=0$ to 7.3 months). Written informed consent is obtained from all participants before they are enrolled in the study, typically at the time of the in-person baseline interview. The study was approved by the IRB of KPNC and all collaborating sites. In order to make these cases comparable with those from the LACE Study, the present analysis includes data from the first 723 women enrolled with a diagnosis of stages $\mathrm{I} \geq 1 \mathrm{~cm}$, II, or IIIA breast cancer and having complete breast cancer subtype data.

\section{Data collection}

\section{Reproductive and lifestyle factors}

In the mailed baseline questionnaire of the LACE Study and during the in-person baseline interview of the Pathways Study, participants were asked detailed information on family history of cancer and reproductive history, including age at first fullterm pregnancy, number of biological children, breastfeeding, and menopausal status. Additional information was collected on smoking, alcohol use, hormone use (oral contraceptives (OC), hormone replacement therapy (HRT)), and demographics (age at breast cancer diagnosis, race/ethnicity, household income, education). Self-reported height and weight one year before diagnosis (LACE) and around diagnosis (Pathways) was obtained to calculate body mass index (BMI, $\left.\mathrm{kg} / \mathrm{m}^{2}\right)$. Any missing values were supplemented by concurrent information from KPNC electronic medical records. 
Table 1

Distribution of demographic, reproductive, and lifestyle risk factors by race/ethnicity in the combined LACE and Pathways Studies ( $n=2544)$

\begin{tabular}{|c|c|c|c|c|c|c|}
\hline & $\begin{array}{c}\text { White Total } n= \\
1943 n(\%)\end{array}$ & $\begin{array}{c}\text { African American } \\
\text { Total } n=155 \text { n (\%) }\end{array}$ & $\begin{array}{c}\text { Asian Total } n= \\
189 \mathrm{n}(\%)\end{array}$ & $\begin{array}{l}\text { Hispanic Total } n \\
=197 \mathrm{n}(\%)\end{array}$ & $\begin{array}{l}\text { Other Total } n= \\
54 n(\%)\end{array}$ & $P$ value \\
\hline Age at diagnosis (years) & & & & & & $<0.0001$ \\
\hline$<50$ & $389(20.0)$ & $43(27.7)$ & $61(32.3)$ & $67(34.0)$ & $13(24.1)$ & \\
\hline 50 to 64 & $879(45.2)$ & $80(51.6)$ & $87(46.0)$ & $80(40.6)$ & $29(53.7)$ & \\
\hline$\geq 65$ & $675(34.7)$ & $32(20.6)$ & $41(21.7)$ & $50(25.4)$ & $12(22.2)$ & \\
\hline $\begin{array}{l}\text { mean }( \pm \text { standard } \\
\text { deviation })\end{array}$ & $59.8(11.2)$ & $56.2(10.7)$ & $54.8(11.0)$ & $55.7(12.4)$ & $57.7(9.8)$ & \\
\hline Menopausal status & & & & & & $<0.0001$ \\
\hline Postmenopausal & $1,330(75.6)$ & $90(71.4)$ & $104(59.1)$ & $117(65.4)$ & $35(72.9)$ & \\
\hline Premenopausal & $430(24.4)$ & $36(28.6)$ & $72(40.9)$ & $62(34.6)$ & $13(27.1)$ & \\
\hline Family history & & & & & & 0.001 \\
\hline No & $1,503(77.4)$ & $133(85.8)$ & $163(86.2)$ & $167(84.8)$ & $41(75.9)$ & \\
\hline Yes & $440(22.6)$ & $22(14.2)$ & $26(13.8)$ & $30(15.2)$ & $13(24.1)$ & \\
\hline Parity & & & & & & 0.006 \\
\hline Nulliparous & $343(17.7)$ & $22(14.2)$ & $46(24.3)$ & $31(15.7)$ & $9(16.7)$ & \\
\hline 1 to 2 children & $894(46.0)$ & $67(43.2)$ & $93(49.2)$ & $79(40.1)$ & $31(57.4)$ & \\
\hline$\geq 3$ children & 706 (36.3) & $66(42.6)$ & $50(26.5)$ & $87(44.2)$ & $14(25.9)$ & \\
\hline $\begin{array}{l}\text { Age at first full-term } \\
\text { pregnancy (years) }\end{array}$ & & & & & & $<0.0001$ \\
\hline Nulliparous & $343(17.7)$ & $22(14.3)$ & $46(24.3)$ & $31(15.8)$ & $9(16.7)$ & \\
\hline$<26$ & $1,020(52.6)$ & $113(73.4)$ & 61 (32.3) & $119(60.7)$ & $28(51.9)$ & \\
\hline$\geq 26$ & $578(29.8)$ & $19(12.3)$ & $82(43.4)$ & $46(23.5)$ & $17(31.5)$ & \\
\hline $\begin{array}{l}\text { Lifetime duration of } \\
\text { lactation }\end{array}$ & & & & & & 0.215 \\
\hline Never & $908(47.3)$ & $92(59.7)$ & $81(44.3)$ & $91(48.1)$ & $25(47.2)$ & \\
\hline 0 to 3 months & $279(14.5)$ & $19(12.3)$ & $31(16.9)$ & $25(13.2)$ & $8(15.1)$ & \\
\hline$\geq 4$ months & $733(38.2)$ & $43(27.9)$ & $71(38.8)$ & $73(38.6)$ & $20(37.7)$ & \\
\hline Alcohol use & & & & & & $<0.0001$ \\
\hline Never & 675 (39.9) & $77(67.5)$ & $116(75.3)$ & $93(62.4)$ & $28(57.1)$ & \\
\hline Ever & $1,016(60.1)$ & $37(32.5)$ & $38(24.7)$ & $56(37.6)$ & $21(42.9)$ & \\
\hline Smoking history (years) & & & & & & $<0.0001$ \\
\hline Never & $925(48.0)$ & $73(47.4)$ & $148(78.3)$ & $113(57.4)$ & $22(40.7)$ & \\
\hline$\leq 10$ & $269(14.0)$ & $17(11.0)$ & $13(6.9)$ & $33(16.8)$ & $6(11.1)$ & \\
\hline 11 to 19 & $169(8.8)$ & $10(6.5)$ & $8(4.2)$ & $6(3.0)$ & $5(9.3)$ & \\
\hline$\geq 20$ & $563(29.2)$ & $54(35.1)$ & $20(10.6)$ & $45(22.8)$ & $21(38.9)$ & \\
\hline \multicolumn{7}{|l|}{$\begin{array}{l}\text { Hormone replacement } \\
\text { therapy (postmenopausal } \\
\text { women only) }\end{array}$} \\
\hline Never & $310(23.8)$ & $37(42.1)$ & $47(45.6)$ & $37(32.2)$ & $12(34.3)$ & \\
\hline Ever & $994(76.2)$ & $51(57.9)$ & $56(54.4)$ & $78(67.8)$ & $23(65.7)$ & \\
\hline Oral contraceptive use & & & & & & $<0.0001$ \\
\hline
\end{tabular}


Table 1 (Continued)

\begin{tabular}{|c|c|c|c|c|c|c|}
\hline Never & $638(33.8)$ & $40(26.7)$ & $100(55.9)$ & $72(37.7)$ & $16(30.2)$ & \\
\hline Ever & $1,252(66.2)$ & $110(73.3)$ & $79(44.1)$ & $119(62.3)$ & $37(69.8)$ & \\
\hline Body mass index $\left(\mathrm{kg} / \mathrm{m}^{2}\right)^{\mathrm{b}}$ & & & & & & $<0.0001$ \\
\hline$<25$ & $835(43.4)$ & $31(20.0)$ & 119 (63.3) & $63(32.5)$ & $20(37.0)$ & \\
\hline 25 to 29 & $600(31.1)$ & $48(31.0)$ & $46(24.5)$ & $64(33.0)$ & $14(25.9)$ & \\
\hline$\geq 30$ & $491(25.5)$ & $76(49.0)$ & $23(12.2)$ & $67(34.5)$ & $20(37.0)$ & \\
\hline
\end{tabular}

a From Pearson chi-square test across racial/ethnic categories.

b Body mass index one year pre-diagnosis (LACE) and around diagnosis (Pathways).

Tumor characteristics

Data on ER and PR status and Her2 expression were obtained from medical record review and the KPNC Cancer Registry [46] for LACE and from the KPNC Cancer Registry and other KPNC databases for Pathways. Data are collected, coded, and added to the KPNC Cancer Registry approximately four months after diagnosis to allow for the completion of treatment. For all breast surgical specimens, hormone receptor status, and Her2 expression is determined by IHC at the KPNC regional IHC laboratory and has been reported to the KPNC Cancer Registry since January 2000. Gene expression profiling studies have shown that $\mathrm{IHC}$ of paraffin sections is a reliable surrogate for molecular classification of invasive breast cancers [3,47-51]. Beginning in July 1999, if the IHC staining for Her2 expression is equivocal (less than 30\% strong staining, but more than $10 \%$ weak staining), then the specimen is sent for fluorescence in situ hybridization (FISH) at the KPNC regional cytogenetics laboratory. If the FISH score (Her2: 17 cen) is less than 2.0 [52], then the woman is classified as having Her2-negative tumor expression; if the FISH score is greater than 2.0, then the woman is classified as having Her2positive tumor expression. Results from FISH analyses are not reported to the KPNC Cancer Registry, and are obtained directly from the KPNC regional cytogenetics laboratory.

\section{Covariate classification}

Demographic, reproductive, and lifestyle covariates of interest were classified as follows: age at diagnosis $(<50,50$ to $64, \geq$ 65 years), race/ethnicity (white, African American, Hispanic, Asian, other), menopausal status (pre, post), family history of breast cancer (no, yes), parity (nulliparous, 1 to $2, \geq 3$ children), age at first full-term pregnancy (nulliparous, $<26, \geq 26$ years), lifetime duration of lactation (never, 0 to $3, \geq 4$ months), alcohol use (never, ever), smoking duration (never, $\leq 10,11$ to $19, \geq 20$ years), hormone replacement therapy (HRT) among post-menopausal women (never, ever), OC use (never, ever), and $\mathrm{BMI}\left(<25,25\right.$ to $\left.29, \geq 30 \mathrm{~kg} / \mathrm{m}^{2}\right)$.

\section{Outcome classification}

Although the presence of basal markers can significantly improve the prognostic value of the triple-negative phenotype
[13], for this analysis, we did not have IHC data for CK5/6 and EGFR expression. Thus, we were unable to further classify triple-negative cases into basal-like and non-basal-like breast tumors. Considering this limitation, the tumor subtype groups in this analysis consisted of: ER positive and/or PR positive, and Her2 negative (luminal A); ER positive and/or PR positive, and Her2 positive (luminal B); ER negative, PR negative, and Her2 negative (triple negative); ER negative, PR negative, and Her2 positive (Her2-overexpressing).

\section{Statistical analysis}

Comparisons of demographic, reproductive, and lifestyle characteristics by cohort study and race/ethnicity were conducted using Pearson chi-square tests. Using the combined sample size of 2544 breast cancer survivors, case-only odds ratios (ORs) and 95\% confidence intervals (Cls) were estimated using logistic regression. The luminal A group was selected as the referent because the majority of invasive breast cancer cases are of this subtype. All models were adjusted for age at diagnosis, race/ethnicity, and Pathways/LACE study origin except when these covariates were the predictors of interest. We also examined whether the associations between parity and tumor subtype varied by breastfeeding and whether BMI and tumor subtype varied by menopausal status by first generating strata-specific estimates and then including an interaction term in the model to test for statistical significance. Cls not overlapping with 1.00 or $P<0.05$ were considered statistically significant.

\section{Results}

Demographic, reproductive, and lifestyle factors varied significantly by race/ethnicity in the combined studies (Table 1). Demographically, African Americans (mean age $=56.2$ years) and Asians (mean age $=54.8$ years) were more likely to be diagnosed at a younger age although whites were more likely to be diagnosed at an older age (mean age $=59.8$ years). However, Asians (59.1\%) were less likely to be post-menopausal than whites (75.6\%), African Americans (71.4\%), and other races/ethnicities (72.9\%). A positive family history of breast cancer was more common among whites $(22.6 \%)$ and other races/ethnicities $(24.1 \%)$, than among the other groups. 
Reproductive history also differed markedly by race/ethnicity; African Americans and Hispanics had more biological children $(42.6 \%$ and $44.2 \%$, respectively) and were younger during their first pregnancy $(73.4 \%$ and $60.7 \%)$ compared with the other races/ethnicities. Whites were more likely to have ever consumed alcohol (60.1\%) while Asians (78.3\%) were more likely to have never smoked. Among the hormonal factors, more whites had used HRT (76.2\%) compared with the other races/ethnicities, while fewer Asians (44.1\%) had used OCs compared with the other races/ethnicities. African Americans were more obese at diagnosis (49.0\%) followed by other races/ethnicities (37.0\%) and Hispanics (34.5\%). Additional data file 2 shows the distribution of demographic, reproductive, and lifestyle factors in the LACE and Pathways Studies separately. Overall, the two study populations were similar demographically, yet non-similarities were apparent among reproductive and hormonal factors, likely to be due to differences in time periods of data collection.

The distribution of breast cancer subtypes by race/ethnicity in the combined studies is presented in Table 2. Among the 2544 invasive breast cancer cases, 1868 (73.4\%) were classified as luminal A, $294(11.6 \%)$ as luminal B, $288(11.3 \%)$ as triple negative, and 94 (3.7\%) as Her2-overexpressing. The distribution of race/ethnicity within each subtype compared with all other subtypes varied significantly $(P<0.05)$. The majority of the whites (75.3\%), Asians (71.4\%), Hispanics (68.5\%), other (68.5\%), and African Americans (59.4\%) had the luminal $A$ tumor subtype. The Her2-overexpressing subtype was least common among all races/ethnicities (whites 3.1\%, African Americans 3.2\%, Asians 6.4\%, Hispanics 6.6\%, other $5.5 \%$ ). African Americans had the highest prevalence of the triple negative subtype (28.4\%) compared with the other races/ethnicities (whites 10.5\%, Asians 6.3\%, Hispanics $10.7 \%$, other $13.0 \%)$.
The associations between various demographic, reproductive, and lifestyle factors within each subtype (luminal $B$, triple negative, and Her2-overexpressing) compared with luminal $A$ are shown in Tables 3 and 4. All case-only ORs were adjusted for age, race/ethnicity, and Pathways/LACE study origin except when either age at diagnosis or race/ethnicity were the main predictors in the logistic regression model. Compared with luminal $A$ cases, luminal $B$ cases were more likely to be younger at diagnosis (OR for $<50$ years $=1.83,95 \% \mathrm{Cl}=$ 1.32 to $2.55 ; P=0.0001$ ) and were less likely to consume alcohol $(\mathrm{OR}=0.74,95 \% \mathrm{Cl}=0.56$ to 0.98$)$, use HRT (OR= $0.66,95 \% \mathrm{Cl}=0.46$ to 0.94$)$, and $\mathrm{OC}(\mathrm{OR}=0.73,95 \% \mathrm{Cl}$ $=0.55$ to 0.96 ). Compared with luminal $A$ cases, triple negative cases tended to be younger at diagnosis (OR for $<50$ years $=2.78,95 \% \mathrm{Cl}=1.99$ to $3.90 ; P \leq 0.0001)$ and African American $(\mathrm{OR}=3.14,95 \% \mathrm{Cl}=2.12$ to 4.16$)$. Breastfeeding for at least four months was associated with being less likely to have a triple negative tumor, yet this association was of borderline significance $(\mathrm{OR}=0.78,95 \% \mathrm{Cl}=0.59$ to 1.03 ). Compared with luminal A cases, Her2-overexpressing cases were more likely to be younger at diagnosis $(P=0.03)$, similar to luminal $B$ and triple negative cases, and less likely to use HRT (OR $=0.49,95 \% \mathrm{Cl}=0.26$ to 0.79 ), similar to luminal $\mathrm{B}$ cases. Furthermore, Her2-overexpressing cases were more likely to be Hispanic $(\mathrm{OR}=2.19,95 \% \mathrm{Cl}=1.16$ to 4.13$)$ and Asian (OR $=2.02,95 \% \mathrm{Cl}=1.05$ to 3.88$)$. The associations between the risk factors and tumor subtypes for the individual studies are presented in Additional data files 3 and 4. The majority of the case-only ORs were in the same direction as observed in the combined analysis, except for the association between BMl and the triple-negative subtype. In the LACE Study, triple-negative cases were more likely to have higher

Table 2

Distribution of breast cancer tumor subtypes by race/ethnicity in the combined LACE and Pathways Studies $(n=2544)$

\begin{tabular}{|c|c|c|c|c|c|c|}
\hline Tumor subtype & White n (\%) & African American n (\%) & Asian n (\%) & Hispanic n (\%) & Other $\mathrm{n}(\%)$ & $P$ value $^{a}$ \\
\hline $\begin{array}{l}\text { Luminal A } \\
\text { (ER+ and/or PR+, Her2-) } \\
\mathrm{n}=1868(73.4)\end{array}$ & $1464(75.3)$ & $92(59.4)$ & $135(71.4)$ & $135(68.5)$ & $37(68.5)$ & 0.0001 \\
\hline $\begin{array}{l}\text { Luminal B } \\
\text { (ER+ and/or PR+, Her2+) } \\
\mathrm{n}=294(11.6)\end{array}$ & $215(11.1)$ & $14(9.0)$ & $30(15.9)$ & $28(14.2)$ & $7(13.0)$ & 0.18 \\
\hline $\begin{array}{l}\text { Triple negative } \\
\text { (ER-, PR-, Her2-) } \\
\mathrm{n}=288(11.3)\end{array}$ & $204(10.5)$ & $44(28.4)$ & $12(6.3)$ & $21(10.7)$ & $7(13.0)$ & $<0.0001$ \\
\hline $\begin{array}{l}\text { Her2 overexpressing } \\
\text { (ER-, PR-, Her2+) } \\
\mathrm{n}=94(3.7)\end{array}$ & $60(3.1)$ & $5(3.2)$ & $12(6.4)$ & $13(6.6)$ & $3(5.5)$ & 0.03 \\
\hline Total $n=2544(100)$ & $1943(100)$ & $155(100)$ & $189(100)$ & $197(100)$ & $54(100)$ & --- \\
\hline
\end{tabular}

a From Pearson chi-square test across racial/ethnic categories.

$\mathrm{ER}=$ estrogen receptor; Her2 $=$ human epidermal growth receptor 2; $\mathrm{PR}=$ progesterone receptor; $+=$ positive; - = negative. 
Table 3

Case-only odds ratios and $95 \%$ confidence intervals from logistic regression modelsa of associations between breast cancer tumor subtypes and demographic, reproductive, and lifestyle risk factors, combined LACE and Pathways Studies $(n=2544)$

\begin{tabular}{|c|c|c|c|c|}
\hline & \multirow{2}{*}{$\frac{\text { Luminal A (comparison) }}{n}$} & \multicolumn{3}{|c|}{ Luminal $\mathrm{Ba}^{\mathrm{a}}$} \\
\hline & & $\mathbf{N}$ & OR & $95 \% \mathrm{Cl}$ \\
\hline \multicolumn{5}{|l|}{ Age at diagnosis (years) } \\
\hline$\geq 65$ (Ref) & 637 & 82 & Ref & --- \\
\hline 50 to 64 & 871 & 124 & 1.09 & $0.81,1.47$ \\
\hline$<50$ & 355 & 88 & 1.83 & $1.32,2.55$ \\
\hline Test for trend & & & & $P=0.0001$ \\
\hline \multicolumn{5}{|l|}{ Race/ethnicity } \\
\hline White (Ref) & 1464 & 215 & Ref & --- \\
\hline African American & 92 & 14 & 0.97 & $0.54,1.74$ \\
\hline Hispanic & 135 & 28 & 1.32 & $0.85,2.04$ \\
\hline Asian & 135 & 30 & 1.38 & $0.90,2.12$ \\
\hline Other & 37 & 7 & 1.29 & $0.56,2.94$ \\
\hline Menopausal status & & & & --- \\
\hline Postmenopausal (Ref) & 1283 & 173 & Ref & \\
\hline Premenopausal & 406 & 95 & 1.32 & $0.87,2.00$ \\
\hline \multicolumn{5}{|l|}{ Family history } \\
\hline No (Ref) & 1453 & 245 & Ref & --- \\
\hline Yes & 410 & 49 & 0.74 & $0.53,1.02$ \\
\hline \multicolumn{5}{|c|}{ Age at first full-term pregnancy (years) } \\
\hline Nulliparous (Ref) & 335 & 51 & Ref & --- \\
\hline$<26$ & 959 & 158 & 1.25 & $0.88,1.78$ \\
\hline$\geq 26$ & 567 & 85 & 1.04 & $0.72,1.52$ \\
\hline \multicolumn{5}{|l|}{ Parity } \\
\hline Nulliparous (Ref) & 335 & 51 & Ref & --- \\
\hline 1 to 2 children & 837 & 150 & 1.24 & $0.88,1.76$ \\
\hline$\geq 3$ children & 691 & 93 & 1.03 & $0.70,1.50$ \\
\hline \multicolumn{5}{|c|}{ Lifetime duration of breastfeeding } \\
\hline Never (Ref) & 871 & 135 & Ref & --- \\
\hline 0 to 3 months & 255 & 50 & 1.31 & $0.92,1.88$ \\
\hline$\geq 4$ months & 711 & 100 & 0.86 & $0.65,1.14$ \\
\hline \multicolumn{5}{|c|}{ Parity among never breastfed } \\
\hline Nulliparous (Ref) & 321 & 50 & Ref & --- \\
\hline 1 to 2 children & 326 & 59 & 1.38 & $(0.89,2.13)$ \\
\hline$\geq 3$ children & 224 & 26 & 1.01 & $(0.58,1.76)$ \\
\hline \multicolumn{5}{|c|}{ Parity among 0 to 3 months breastfed ${ }^{b}$} \\
\hline 1 to 2 children (Ref) & 144 & 33 & Ref & --- \\
\hline$\geq 3$ children & 108 & 17 & 0.90 & $(0.45,1.77)$ \\
\hline
\end{tabular}

Parity among $\geq 4$ months breastfed ${ }^{b}$ 


\begin{tabular}{|c|c|c|c|c|}
\hline 1 to 2 children (Ref) & 358 & 56 & Ref & --- \\
\hline$\geq 3$ children & 352 & 44 & 0.84 & $(0.54,1.32)$ \\
\hline \multicolumn{5}{|l|}{ Alcohol use } \\
\hline Never (Ref) & 709 & 131 & Ref & --- \\
\hline Ever & 880 & 119 & 0.74 & $0.56,0.98$ \\
\hline \multicolumn{5}{|l|}{ Smoking history } \\
\hline Never (Ref) & 921 & 163 & Ref & -- \\
\hline$\leq 10$ & 251 & 39 & 0.86 & $0.59,1.27$ \\
\hline 11 to 19 & 147 & 22 & 0.93 & $0.57,1.51$ \\
\hline$\geq 20$ & 531 & 68 & 0.80 & $0.59,1.09$ \\
\hline \multicolumn{5}{|c|}{ Hormone replacement therapy (postmenopausal only) } \\
\hline Never (Ref) & 314 & 55 & Ref & --- \\
\hline Ever & 943 & 114 & 0.66 & $0.46,0.94$ \\
\hline \multicolumn{5}{|l|}{ Oral contraceptive use } \\
\hline Never (Ref) & 647 & 110 & Ref & --- \\
\hline Ever & 1160 & 172 & 0.73 & $0.55,0.96$ \\
\hline \multicolumn{5}{|l|}{$\mathrm{BMI}\left(\mathrm{kg} / \mathrm{m}^{2}\right)^{\mathrm{c}}$} \\
\hline$<25$ (Ref) & 785 & 134 & Ref & --- \\
\hline 25 to 29 & 563 & 79 & 0.92 & $0.67,1.24$ \\
\hline$\geq 30$ & 500 & 77 & 1.03 & $0.75,1.41$ \\
\hline \multicolumn{5}{|c|}{ BMI $\left(\mathrm{kg} / \mathrm{m}^{2}\right)$ among premenopausal ${ }^{\mathrm{b}}$} \\
\hline$<25$ (Ref) & 223 & 50 & Ref & --- \\
\hline 25 to 29 & 99 & 21 & 1.11 & $0.62,2.00$ \\
\hline$\geq 30$ & 81 & 24 & 1.68 & $0.92,3.07$ \\
\hline \multicolumn{5}{|c|}{ BMI $\left(\mathrm{kg} / \mathrm{m}^{2}\right)$ among postmenopausal ${ }^{\mathrm{b}}$} \\
\hline$<25$ (Ref) & 480 & 67 & Ref & -- \\
\hline 25 to 29 & 422 & 52 & 0.90 & $0.61,1.33$ \\
\hline$\geq 30$ & 372 & 50 & 0.99 & $0.66,1.47$ \\
\hline
\end{tabular}

a Adjusted for age at diagnosis, race/ethnicity, and Pathways/LACE study origin except in models with age at diagnosis or race/ethnicity as main predictors.

$\mathrm{b} P$ for interaction not statistically significant $(P>0.05)$ in any tumor subtype model.

${ }^{\mathrm{C}} \mathrm{BMI}=$ body mass index one year pre-diagnosis (LACE) and around diagnosis (Pathways).

$\mathrm{Cl}=$ confidence interval; $\mathrm{OR}=$ odds ratio.

BMI while in the Pathways Study the opposite trend was observed, although these effect measures were not statistically significant.

For the subgroup analyses, among non-breastfeeding cases, parity of at least three children was associated with a statistically significant increased likelihood of having a triple-negative tumor $(\mathrm{OR}=1.68 ; 95 \% \mathrm{Cl}=1.00$ to 2.81 ) and a Her2-overexpressing tumor $(\mathrm{OR}=3.03 ; 95 \% \mathrm{Cl}=1.27$ to 7.23 ) compared with luminal $A$. In contrast, no differential associations of breastfeeding and parity were observed among luminal B cases. All $P$ values for interaction of parity by breastfeeding were not statistically significant. As for the effect of BMl by menopausal status, premenopausal triple-negative and Her2overexpressing cases were more likely to be overweight (triple negative: $\mathrm{OR}=1.82,95 \% \mathrm{Cl}=1.03$ to 3.24 ; Her2-overexpressing: $\mathrm{OR}=2.15,95 \% \mathrm{Cl}=0.70$ to 6.58 ) or obese (triple negative: $\mathrm{OR}=1.97,95 \% \mathrm{Cl}=1.03$ to 3.77 ; Her2-overexpressing: $\mathrm{OR}=2.51,95 \% \mathrm{Cl}=0.74$ to 8.51 ) at diagnosis, yet the effect measures for Her2-overexpressing tumors were not 
Table 4

Case-only odds ratios and $95 \%$ confidence intervals from logistic regression modelsa of associations between breast cancer tumor subtypes and demographic, reproductive, and lifestyle risk factors, combined LACE and Pathways Studies $(n=2544)$

\begin{tabular}{|c|c|c|c|c|c|c|c|}
\hline & \multirow{2}{*}{$\frac{\text { Luminal A (comparison) }}{\mathrm{n}}$} & \multicolumn{3}{|c|}{ Triple negative $^{a}$} & \multicolumn{3}{|c|}{ HER2-overexpressinga } \\
\hline & & $\mathbf{n}$ & OR & $95 \% \mathrm{Cl}$ & $\mathbf{n}$ & OR & $95 \% \mathrm{Cl}$ \\
\hline \multicolumn{8}{|l|}{ Age at diagnosis (years) } \\
\hline$\geq 65$ (Ref) & 637 & 68 & Ref & --- & 23 & Ref & --- \\
\hline 50 to 64 & 871 & 115 & 1.99 & $0.85,1.62$ & 45 & 1.39 & $0.83,2.32$ \\
\hline$<50$ & 355 & 105 & 2.78 & $1.99,3.90$ & 25 & 1.75 & $0.97,3.15$ \\
\hline Test for trend & & & & $P \leq 0.0001$ & & & $P=0.03$ \\
\hline \multicolumn{8}{|l|}{ Race/ethnicity } \\
\hline White (Ref) & 1464 & 204 & Ref & --- & 60 & Ref & --- \\
\hline African American & 92 & 44 & 3.14 & $2.12,4.66$ & 5 & 1.25 & $0.49,3.21$ \\
\hline Hispanic & 135 & 21 & 0.93 & $0.57,1.53$ & 13 & 2.19 & $1.16,4.13$ \\
\hline Asian & 135 & 12 & 0.53 & $0.28,0.97$ & 12 & 2.02 & $1.05,3.88$ \\
\hline Other & 37 & 7 & 1.28 & $0.56,2.94$ & 3 & 1.95 & $0.58,6.52$ \\
\hline \multicolumn{8}{|l|}{ Menopausal status } \\
\hline Postmenopausal (Ref) & 1283 & 163 & Ref & --- & 57 & Ref & --- \\
\hline Premenopausal & 406 & 91 & 0.84 & $0.55,1.27$ & 21 & 0.65 & $0.31,1.33$ \\
\hline \multicolumn{8}{|l|}{ Family history } \\
\hline No (Ref) & 1453 & 229 & Ref & --- & 80 & Ref & --- \\
\hline Yes & 410 & 59 & 0.95 & $0.69,1.29$ & 13 & 0.62 & $0.34,1.13$ \\
\hline \multicolumn{8}{|c|}{ Age at first full-term pregnancy (years) } \\
\hline Nulliparous (Ref) & 335 & 52 & Ref & --- & 13 & Ref & --- \\
\hline$<26$ & 959 & 163 & 1.28 & $0.90,1.82$ & 61 & 2.02 & $1.07,3.80$ \\
\hline$\geq 26$ & 567 & 72 & 0.93 & $0.63,1.38$ & 18 & 0.86 & $0.42,1.79$ \\
\hline \multicolumn{8}{|l|}{ Parity } \\
\hline Nulliparous (Ref) & 335 & 52 & Ref & --- & 13 & Ref & --- \\
\hline 1 to 2 children & 837 & 137 & 1.11 & $0.78,1.58$ & 40 & 1.30 & $0.68,2.47$ \\
\hline$\geq 3$ children & 691 & 99 & 1.18 & $0.81,1.72$ & 40 & 1.82 & $0.94,3.53$ \\
\hline \multicolumn{8}{|c|}{ Lifetime duration of breastfeeding } \\
\hline Never (Ref) & 871 & 148 & Ref & --- & 43 & Ref & --- \\
\hline 0 to 3 months & 255 & 41 & 1.04 & $0.71,1.52$ & 16 & 1.29 & $0.71,2.35$ \\
\hline$\geq 4$ months & 711 & 97 & 0.78 & $0.59,1.03$ & 32 & 0.86 & $0.54,1.38$ \\
\hline \multicolumn{8}{|c|}{ Parity among never breastfed ${ }^{b}$} \\
\hline Nulliparous (Ref) & 321 & 50 & Ref & --- & 12 & Ref & --- \\
\hline 1 to 2 children & 326 & 59 & 1.34 & $(0.87,2.08)$ & 15 & 1.52 & $(0.68,3.41)$ \\
\hline$\geq 3$ children & 224 & 39 & 1.68 & $(1.00,2.81)$ & 16 & 3.03 & $(1.27,7.23)$ \\
\hline \multicolumn{8}{|c|}{ Parity among 0 to 3 months breastfed ${ }^{b}$} \\
\hline 1 to 2 children (Ref) & 144 & 25 & Ref & --- & 9 & Ref & --- \\
\hline$\geq 3$ children & 108 & 16 & 1.16 & $(0.53,2.56)$ & 7 & 1.82 & $(0.57,5.80)$ \\
\hline
\end{tabular}

Parity among $\geq 4$ months breastfed ${ }^{b}$ 


\begin{tabular}{|c|c|c|c|c|c|c|c|}
\hline 1 to 2 children (Ref) & 358 & 52 & Ref & --- & 14 & Ref & -- \\
\hline$\geq 3$ children & 352 & 44 & 0.99 & $(0.63,1.55)$ & 17 & 1.23 & $(0.57,2.66)$ \\
\hline \multicolumn{8}{|l|}{ Alcohol use } \\
\hline Never (Ref) & 709 & 110 & Ref & --- & 39 & Ref & --- \\
\hline Ever & 880 & 129 & 0.98 & $0.73,1.30$ & 40 & 0.94 & $0.59,1.50$ \\
\hline \multicolumn{8}{|l|}{ Smoking history } \\
\hline Never (Ref) & 921 & 146 & Ref & --- & 51 & Ref & --- \\
\hline$\leq 10$ & 251 & 41 & 0.95 & $0.65,1.40$ & 7 & 0.51 & $0.23,1.14$ \\
\hline 11 to 19 & 147 & 21 & 0.89 & $0.54,1.47$ & 8 & 1.17 & $0.54,2.56$ \\
\hline$\geq 20$ & 531 & 78 & 0.98 & $0.72,1.34$ & 26 & 1.05 & $0.63,1.73$ \\
\hline \multicolumn{8}{|c|}{ Hormone replacement therapy (postmenopausal only) } \\
\hline Never (Ref) & 314 & 50 & Ref & --- & 24 & Ref & --- \\
\hline Ever & 943 & 112 & 0.83 & $0.57,1.20$ & 33 & 0.45 & $0.26,0.79$ \\
\hline \multicolumn{8}{|l|}{ Oral contraceptive use } \\
\hline Never (Ref) & 647 & 80 & Ref & --- & 29 & Ref & --- \\
\hline Ever & 1160 & 202 & 0.97 & $0.72,1.31$ & 63 & 1.12 & $0.69,1.83$ \\
\hline \multicolumn{8}{|l|}{ BMl $\left(\mathrm{kg} / \mathrm{m}^{2}\right)^{\mathrm{c}}$} \\
\hline$<25$ (Ref) & 785 & 110 & Ref & --- & 39 & Ref & -- \\
\hline 25 to 29 & 563 & 99 & 1.33 & $0.98,1.81$ & 31 & 1.21 & $0.74,1.99$ \\
\hline$\geq 30$ & 500 & 77 & 1.04 & $0.75,1.45$ & 23 & 1.03 & $0.59,1.78$ \\
\hline \multicolumn{8}{|c|}{ BMI $\left(\mathrm{kg} / \mathrm{m}^{2}\right)$ among premenopausal ${ }^{\mathrm{b}}$} \\
\hline$<25$ (Ref) & 223 & 39 & Ref & --- & 7 & Ref & -- \\
\hline 25 to 29 & 99 & 28 & 1.82 & $1.03,3.24$ & 7 & 2.15 & $0.70,6.58$ \\
\hline$\geq 30$ & 81 & 23 & 1.97 & $1.03,3.77$ & 7 & 2.51 & $0.74,8.51$ \\
\hline \multicolumn{8}{|c|}{$\mathrm{BMI}\left(\mathrm{kg} / \mathrm{m}^{2}\right)$ among postmenopausalb } \\
\hline$<25$ (Ref) & 480 & 59 & Ref & --- & 25 & Ref & --- \\
\hline 25 to 29 & 422 & 60 & 1.08 & $0.73,1.59$ & 18 & 0.86 & $0.46,1.61$ \\
\hline$\geq 30$ & 372 & 43 & 0.76 & $0.49,1.17$ & 14 & 0.76 & $0.38,1.51$ \\
\hline
\end{tabular}

a Adjusted for age at diagnosis, race/ethnicity, and Pathways/LACE study origin except in models with age at diagnosis or race/ethnicity as main predictors.

$\mathrm{b} P$ for interaction not statistically significant $(P>0.05)$ in any tumor subtype model.

${ }^{\mathrm{c}} \mathrm{BMI}$, body mass index one year pre-diagnosis (LACE) and around diagnosis (Pathways).

$\mathrm{Cl}=$ confidence interval; HER2 = human epidermal growth receptor 2; OR = odds ratio.

statistically significant. Among luminal A cases, these associations were not observed. All $P$ values for interaction of BMl by menopausal status were not statistically significant.

\section{Discussion}

In a pooled analysis of 2544 breast cancer cases using data from two prospective cohort studies housed within a large health maintenance organization, associations between breast cancer subtypes and various demographic, reproductive, and lifestyle factors were examined. In case-case analyses with the luminal $A$ cases as the reference group, luminal $B$ cases were more likely to be younger at diagnosis and were less likely to consume alcohol, use HRT, and OCs. Triple-negative cases tended to be younger at diagnosis and African American, and were more likely to be overweight and/or obese at diagnosis if premenopausal. Women with triple-negative tumors were also less likely to breastfeed for longer periods, and were more likely to not breastfeed if they had at least three children. Her2overexpressing cases were more likely to be younger at diagnosis and Hispanic or Asian, and less likely to use HRT. We 
also found that these cases were more likely to be women with at least three children and no history of breastfeeding. These case-case observations suggest that heterogeneity in associations with traditional breast cancer risk factors exists by tumor subtype.

Several studies have assessed risk factor profiles of tumor subtypes, including the Carolina Breast Cancer Study (CBCS; $n=1424$ in situ and invasive cases) [22], the Polish Breast Cancer Study (PBCS; 804 invasive cases) [27], and a pooled study of two Washington State (WS) case-control studies ( $n=1023$ invasive cases) $[42,43$ ] [see Additional data file 1]. The CBCS and PBCS were able to classify their triplenegative cases into basal-like and unclassified using CK5/6 and EGFR IHC expression data while the WS study did not do so. The CBCS performed case-case and case-control analyses while the PBCS and WS study conducted case-control analyses only. Although we were unable to further classify triple-negative cases into basal-like and unclassified, similar to the results of the CBCS (case-case analysis) and PBCS (case-control analysis) for basal-like cases, our triple-negative cases were more likely to be younger at diagnosis and African American. We also observed that premenopausal triple-negative cases tended to have higher BMI, which was in agreement with the basal-like cases in the CBCS but not the PBCS, the latter of which found no association. Interestingly, the WS study (case-control analysis) reported a suggestive increased risk of triple-negative tumors with increasing BMl among women currently using hormone therapy [42], yet we did not see any such association in our study. The WS study (casecontrol analysis) also reported that breastfeeding for at least six months was related to a reduced risk of triple-negative tumors [43]. Similarly, both the CBCS (case-case analysis) and our study found suggestive associations of shorter duration of breastfeeding (less than four months) with being more likely to have a triple-negative tumor. Furthermore, both studies observed a strong positive association for triple-negative cases (basal-like cases for CBCS) among women who had higher parity and never breastfed; the CBCS reported a caseonly OR for parity of at least three children and no breastfeeding as $1.9(95 \% \mathrm{Cl}=1.1$ to 3.4$)$ compared with luminal $A$ cases. The PBCS (case-control analysis) did not present data on the impact of breastfeeding on tumor subtypes.

As for luminal B and Her2-overexpressing cases, our results are in agreement with those of the CBCS that luminal $B$ and Her2-overexpressing cases tended to be younger than luminal A cases. In contrast to the CBCS results, we observed that these cases were less likely to use HRT although luminal B cases were less likely to consume alcohol. No associations with these factors were observed in the PBCS, and the WS study did not examine luminal tumors separately by luminal $A$ and luminal $B$ subtype. We found that Her2-overexpressing cases were more likely to be Hispanic or Asian, but not African American, an observation which was not seen in any of the other studies. In fact, the CBCS, comprised of only whites and African Americans, reported that Her2-overexpressing cases were slightly more likely to be African American. Finally, we observed that Her2-overexpressing cases were more likely to be women who had at least three children and had not breastfed, an association not seen in the CBCS.

Although our results tend to be in agreement with those of other studies, limitations of our study should be discussed. Only case-case comparisons were conducted, and it must be emphasized that the associations reported here are all in reference to risk of having a luminal A tumor subtype and should not be extended to risk of having invasive breast cancer. Casecase analyses among tumor subtypes are a useful exploratory tool to examine etiologic heterogeneity between the subtypes [53]. As previously mentioned, we have no data on CK5/6 and EGFR tumor markers to further classify triple-negative tumors into basal-like and unclassified. However, with additional funding, we plan to conduct these additional IHC assays in triple negative cases. Also, as there were a limited number of Her2overexpressing tumors $(n=94 ; 3.7 \%)$, results concerning this subtype should be interpreted with caution. Finally, although our large study population of 2544 women diagnosed with invasive breast cancer was more ethnically diverse $(76.6 \%$ white, 6.1\% African American, 7.8\% Hispanic, 7.4\% Asian, $2.1 \%$ other) than other studies that have examined breast cancer risk factors among tumor subtypes, unlike the CBCS, we were unable to further examine risk factors by white and African American race/ethnicity due to limited numbers. Our findings, especially those regarding Hispanic and Asian differences, should be replicated in other population-based studies.

\section{Conclusions}

In summary, using a case-case analysis to assess the associations between traditional breast cancer risk factors and breast cancer subtypes (luminal A, luminal B, triple negative, and Her2-overexpressing), we observed significant heterogeneity of associations by tumor subtype. These varying associations by subtype lend further support to the growing evidence base that breast cancer is a heterogeneous disease defined by ER, PR, and Her2 expression with distinct etiologic pathways and prognoses. Future research should focus on refinement of tumor subtypes into more homogenous subgroups in order to best elucidate how risk factors may vary by subtype. Important modifiable factors that may be related to the development of specific tumor subtypes include obesity and possibly breastfeeding (triple negative) and alcohol consumption (luminal B), yet no clear modifiable risk factor profile was apparent for Her2-overexpressing subtypes due to a limited sample size. Given this information, public health programs aimed towards achieving a healthy weight and promoting breastfeeding might reduce the number of poor prognostic triple negative tumors among all breast cancer cases, especially the high-risk African American group. 


\section{Competing interests}

The authors declare that they have no competing interests.

\section{Authors' contributions}

MLK contributed to study conception and design, and acquisition, analysis, and interpretation of data; and drafted and revised the manuscript critically for important intellectual content. LHK and BJC contributed to study conception and design, and acquisition, analysis, and interpretation of data; and revised the manuscript critically for important intellectual content. EW contributed to analysis and interpretation of data; and revised the manuscript critically for important intellectual content. BM contributed to study conception and design; and revised the manuscript critically for important intellectual content. SEK contributed to analysis and interpretation of data; and revised the manuscript critically for important intellectual content. RSF contributed to acquisition of data; and revised the manuscript critically for important intellectual content. MML contributed to analysis and interpretation of data; and revised the manuscript critically for important intellectual content. CBA contributed to analysis and interpretation of data; and revised the manuscript critically for important intellectual content. All authors read and approved the final manuscript.

\section{Additional files}

The following Additional files are available online:

\section{Additional file 1}

A word file containing a table that lists previous studies that have examined associations between common breast cancer risk factors and breast cancer tumor subtypes.

See http://www.biomedcentral.com/content/ supplementary/bcr2261-S1.doc

\section{Additional file 2}

A word file containing a table that lists the distribution of demographic, reproductive, and lifestyle risk factors in the LACE and Pathways studies individually and combined ( $n=2544)$.

See http://www.biomedcentral.com/content/ supplementary/bcr2261-S2.doc

\section{Additional file 3}

A word file containing a table that lists case-only odds ratios and $95 \%$ confidence intervals from logistic regression models of associations between breast cancer tumor subtypes and demographic, reproductive, and lifestyle risk factors, LACE study $(n=1821)$. See http://www.biomedcentral.com/content/ supplementary/bcr2261-S3.doc

\section{Additional file 4}

A word file containing a table that shows case-only odds ratios and 95\% confidence intervals from logistic regression models of associations between breast cancer tumor subtypes and demographic, reproductive, and lifestyle risk factors, Pathways study $(n=723)$. See http://www.biomedcentral.com/content/ supplementary/bcr2261-S4.doc

\section{Acknowledgements}

The LACE Study was funded by the National Cancer Institute (R01 CA80027) and by the Utah Cancer Registry (N01 PC67000), with additional support from the State of Utah Department of Health. The Pathways Study was funded by the National Cancer Institute (R01 CA105274, R01 CA124924), the Department of Defense (BC043120), and the American Cancer Society (RSG-06-209-01-LR). We thank all LACE and Pathways Study participants, as well as the office and field staff. We acknowledge the technical assistance of Dr Xu $\mathrm{Li}$ of the KPNC Cytogenetics Laboratory and the programming assistance of Isaac Joshua Ergas at Kaiser Permanente, Division of Research. The contents of this manuscript are solely the responsibility of the authors and do not necessarily represent the official views of the funding agencies.

\section{References}

1. American Cancer Society: Cancer facts and figures 2008. Atlanta: American Cancer Society; 2008.

2. Carey LA, Perou CM, Livasy CA, Dressler LG, Cowan D, Conway K, Karaca G, Troester MA, Tse CK, Edmiston S, Deming SL, Geradts J, Cheang MC, Nielsen TO, Moorman PG, Earp HS, Millikan RC: Race, breast cancer subtypes, and survival in the Carolina Breast Cancer Study. JAMA 2006, 295:2492-2502.

3. Nielsen TO, Hsu FD, Jensen K, Cheang M, Karaca G, Hu Z, Hernandez-Boussard T, Livasy C, Cowan D, Dressler L, Akslen LA, Ragaz J, Gown AM, Gilks CB, Rijn M van de, Perou CM: Immunohistochemical and clinical characterization of the basal-like subtype of invasive breast carcinoma. Clin Cancer Res 2004, 10:5367-5374.

4. Perou CM, Sorlie T, Eisen MB, Rijn M van de, Jeffrey SS, Rees CA, Pollack JR, Ross DT, Johnsen H, Akslen LA, Fluge O, Pergamenschikov A, Williams C, Zhu SX, Lonning PE, Borresen-Dale AL, Brown PO, Botstein D: Molecular portraits of human breast tumours. Nature 2000, 406:747-752.

5. Rakha EA, El-Rehim DA, Paish C, Green AR, Lee AH, Robertson JF, Blamey RW, Macmillan D, Ellis IO: Basal phenotype identifies a poor prognostic subgroup of breast cancer of clinical importance. Eur J Cancer 2006, 42:3149-3156.

6. Sorlie T, Perou CM, Tibshirani R, Aas T, Geisler S, Johnsen H, Hastie T, Eisen MB, Rijn M van de, Jeffrey SS, Thorsen T, Quist $H_{\text {, }}$ Matese JC, Brown PO, Botstein D, Eystein Lonning P, BorresenDale AL: Gene expression patterns of breast carcinomas distinguish tumor subclasses with clinical implications. Proc Nat/ Acad Sci USA 2001, 98:10869-10874.

7. Bertucci F, Finetti P, Cervera N, Esterni B, Hermitte F, Viens P, Birnbaum D: How basal are triple-negative breast cancers? Int J Cancer 2008, 123:236-240.

8. Bidard FC, Conforti R, Boulet T, Michiels S, Delaloge S, Andre F: Does triple-negative phenotype accurately identify basal-like tumour? An immunohistochemical analysis based on 143 'triple-negative' breast cancers. Ann Oncol 2007, 18:1285-1286.

9. Tan DS, Marchio C, Jones RL, Savage K, Smith IE, Dowsett M, Reis-Filho JS: Triple negative breast cancer: molecular profiling and prognostic impact in adjuvant anthracycline-treated patients. Breast Cancer Res Treat 2008, 111:27-44. 
10. Bauer KR, Brown M, Cress RD, Parise CA, Caggiano V: Descriptive analysis of estrogen receptor (ER)-negative, progesterone receptor (PR)-negative, and HER2-negative invasive breast cancer, the so-called triple-negative phenotype: a populationbased study from the California cancer Registry. Cancer 2007, 109:1721-1728.

11. Brown M, Tsodikov A, Bauer KR, Parise CA, Caggiano V: The role of human epidermal growth factor receptor 2 in the survival of women with estrogen and progesterone receptor-negative, invasive breast cancer: the California Cancer Registry, 19992004. Cancer 2008, 112:737-747.

12. Carey LA, Dees EC, Sawyer L, Gatti L, Moore DT, Collichio F, Ollila DW, Sartor Cl, Graham ML, Perou CM: The triple negative paradox: primary tumor chemosensitivity of breast cancer subtypes. Clin Cancer Res 2007, 13:2329-2334.

13. Cheang MC, Voduc D, Bajdik C, Leung S, McKinney S, Chia SK, Perou CM, Nielsen TO: Basal-like breast cancer defined by five biomarkers has superior prognostic value than triple-negative phenotype. Clin Cancer Res 2008, 14:1368-1376.

14. Dent R, Trudeau M, Pritchard KI, Hanna WM, Kahn HK, Sawka CA, Lickley LA, Rawlinson E, Sun P, Narod SA: Triple-negative breast cancer: clinical features and patterns of recurrence. Clin Cancer Res 2007, 13:4429-4434.

15. Harris LN, Broadwater G, Lin NU, Miron A, Schnitt SJ, Cowan D, Lara J, Bleiweiss I, Berry D, Ellis M, Hayes DF, Winer EP, Dressler $\mathrm{L}$ : Molecular subtypes of breast cancer in relation to paclitaxel response and outcomes in women with metastatic disease: results from CALGB 9342. Breast Cancer Res 2006, 8:R66.

16. Ihemelandu CU, Leffall LD Jr, Dewitty RL, Naab TJ, Mezghebe HM, Makambi KH, Adams-Campbell L, Frederick WA: Molecular breast cancer subtypes in premenopausal and postmenopausal African-American women: age-specific prevalence and survival. J Surg Res 2007, 143:109-118.

17. Lund MJ, Trivers KF, Porter PL, Coates RJ, Leyland-Jones B, Brawley OW, Flagg EW, O'Regan RM, Gabram SG, Eley JW: Race and triple negative threats to breast cancer survival: a populationbased study in Atlanta, GA. Breast Cancer Res Treat 2009, 113:357-370

18. Kurebayashi J, Moriya $T$, Ishida $T$, Hirakawa $H$, Kurosumi M, Akiyama F, Kinoshita T, Takei $H$, Takahashi K, Ikeda M, Nakashima K: The prevalence of intrinsic subtypes and prognosis in breast cancer patients of different races. Breast 2007, 16(Suppl 2):S72-77.

19. Tischkowitz M, Brunet JS, Begin LR, Huntsman DG, Cheang MC, Akslen LA, Nielsen TO, Foulkes WD: Use of immunohistochemical markers can refine prognosis in triple negative breast cancer. BMC Cancer 2007, 7:134.

20. Stark A, Kapke A, Schultz D, Brown R, Linden M, Raju U: Advanced stages and poorly differentiated grade are associated with an increased risk of HER2/neu positive breast carcinoma only in White women: findings from a prospective cohort study of African-American and White-American women. Breast Cancer Res Treat 2008, 107:405-414.

21. Bowen RL, Duffy SW, Ryan DA, Hart IR, Jones JL: Early onset of breast cancer in a group of British black women. $\mathrm{Br} J$ Cancer 2008, 98:277-281.

22. Millikan RC, Newman B, Tse CK, Moorman PG, Conway K, Smith LV, Labbok MH, Geradts J, Bensen JT, Jackson S, Nyante S, Livasy C, Carey L, Earp HS, Perou CM: Epidemiology of basal-like breast cancer. Breast Cancer Res Treat 2008, 109:123-139.

23. Haffty BG, Yang Q, Reiss M, Kearney T, Higgins SA, Weidhaas J, Harris L, Hait W, Toppmeyer D: Locoregional relapse and distant metastasis in conservatively managed triple negative early-stage breast cancer. J Clin Oncol 2006, 24:5652-5657.

24. Lund MJ, Butler EN, Bumpers HL, Okoli J, Rizzo M, Hatchett N, Green VL, Brawley OW, Oprea-llies GM, Gabram SG: High prevalence of triple-negative tumors in an urban cancer center. Cancer 2008, 113:608-615.

25. Morris GJ, Naidu S, Topham AK, Guiles F, Xu Y, McCue P, Schwartz GF, Park PK, Rosenberg AL, Brill K, Mitchell EP: Differences in breast carcinoma characteristics in newly diagnosed African-American and Caucasian patients: a single-institution compilation compared with the National Cancer Institute's Surveillance, Epidemiology, and End Results database. Cancer 2007, 110:876-884.
26. Livasy CA, Karaca G, Nanda R, Tretiakova MS, Olopade OI, Moore DT, Perou CM: Phenotypic evaluation of the basal-like subtype of invasive breast carcinoma. Mod Pathol 2006, 19:264-271.

27. Yang XR, Sherman ME, Rimm DL, Lissowska J, Brinton LA, Peplonska B, Hewitt SM, Anderson WF, Szeszenia-Dabrowska N, Bardin-Mikolajczak A, Zatonski W, Cartun R, Mandich D, Rymkiewicz G, Ligaj M, Lukaszek S, Kordek R, Garcia-Closas M: Differences in risk factors for breast cancer molecular subtypes in a population-based study. Cancer Epidemiol Biomarkers Prev 2007, 16:439-443.

28. Parikh RR, Yang $Q$, Higgins SA, Haffty BG: Outcomes in young women with breast cancer of triple-negative phenotype: the prognostic significance of CK19 expression. Int J Radiat Oncol Biol Phys 2008, 70:35-42.

29. Sorlie T, Tibshirani R, Parker J, Hastie T, Marron JS, Nobel A, Deng $\mathrm{S}$, Johnsen H, Pesich R, Geisler S, Demeter J, Perou CM, Lonning PE, Brown PO, Borresen-Dale AL, Botstein D: Repeated observation of breast tumor subtypes in independent gene expression data sets. Proc Natl Acad Sci USA 2003, 100:8418-8423.

30. Brinton LA, Benichou J, Gammon MD, Brogan DR, Coates R, Schoenberg JB: Ethnicity and variation in breast cancer incidence. Int J Cancer 1997, 73:349-355.

31. Chlebowski RT, Chen Z, Anderson GL, Rohan T, Aragaki A, Lane D, Dolan NC, Paskett ED, McTiernan A, Hubbell FA, AdamsCampbell LL, Prentice R: Ethnicity and breast cancer: factors influencing differences in incidence and outcome. J Nat/ Cancer Inst 2005, 97:439-448.

32. Hall IJ, Moorman PG, Millikan RC, Newman B: Comparative analysis of breast cancer risk factors among African-American women and White women. Am J Epidemiol 2005, 161:40-51.

33. Mayberry RM, Stoddard-Wright C: Breast cancer risk factors among black women and white women: similarities and differences. Am J Epidemiol 1992, 136:1445-1456.

34. Moorman PG, Millikan RC, Newman B: Oral contraceptives and breast cancer among African-american women and white women. J Natl Med Assoc 2001, 93:329-334.

35. Palmer JR, Wise LA, Horton NJ, Adams-Campbell LL, Rosenberg $\mathrm{L}$ : Dual effect of parity on breast cancer risk in African-American women. J Natl Cancer Inst 2003, 95:478-483.

36. Ursin G, Bernstein L, Wang Y, Lord SJ, Deapen D, Liff JM, Norman SA, Weiss LK, Daling JR, Marchbanks PA, Malone KE, Folger SG, McDonald JA, Burkman RT, Simon MS, Strom BL, Spirtas R: Reproductive factors and risk of breast carcinoma in a study of white and African-American women. Cancer 2004, 101:353-362.

37. Colditz GA, Rosner BA, Chen WY, Holmes MD, Hankinson SE: Risk factors for breast cancer according to estrogen and progesterone receptor status. J Natl Cancer Inst 2004, 96:218-228

38. Huang WY, Newman B, Millikan RC, Schell MJ, Hulka BS, Moorman PG: Hormone-related factors and risk of breast cancer in relation to estrogen receptor and progesterone receptor status. Am J Epidemiol 2000, 151:703-714.

39. Lord SJ, Bernstein L, Johnson KA, Malone KE, McDonald JA Marchbanks PA, Simon MS, Strom BL, Press MF, Folger SG, Burkman RT, Deapen D, Spirtas R, Ursin G: Breast cancer risk and hormone receptor status in older women by parity, age of first birth, and breastfeeding: a case-control study. Cancer Epidemiol Biomarkers Prev 2008, 17:1723-1730.

40. $\mathrm{Ma} \mathrm{H}$, Bernstein L, Pike MC, Ursin G: Reproductive factors and breast cancer risk according to joint estrogen and progesterone receptor status: a meta-analysis of epidemiological studies. Breast Cancer Res 2006, 8:R43.

41. Potter JD, Cerhan JR, Sellers TA, McGovern PG, Drinkard C, Kushi $\mathrm{LR}$, Folsom AR: Progesterone and estrogen receptors and mammary neoplasia in the lowa Women's Health Study: how many kinds of breast cancer are there? Cancer Epidemiol Biomarkers Prev 1995, 4:319-326.

42. Phipps Al, Malone KE, Porter PL, Daling JR, Li Cl: Body size and risk of luminal, HER2-overexpressing, and triple-negative breast cancer in postmenopausal women. Cancer Epidemiol Biomarkers Prev 2008.

43. Phipps Al, Malone KE, Porter PL, Daling JR, Li Cl: Reproductive and hormonal risk factors for postmenopausal luminal, HER2-overexpressing, and triple-negative breast cancer. Cancer 2008, 113:1521-1526. 
44. Caan B, Sternfeld B, Gunderson E, Coates A, Quesenberry C, Slattery ML: Life After Cancer Epidemiology (LACE) Study: a cohort of early stage breast cancer survivors (United States). Cancer Causes Control 2005, 16:545-556.

45. Kushi LH, Kwan ML, Lee MM, Ambrosone CB: Lifestyle factors and survival in women with breast cancer. J Nutr 2007, 137:236S-242S.

46. Oehrli MD, Quesenberry CP, Leyden W: 2006 annual report on trends, incidence, and outcomes. Kaiser Permanente, Northern California Cancer Registry; 2006.

47. Abd El-Rehim DM, Ball G, Pinder SE, Rakha E, Paish C, Robertson $\mathrm{JF}$, Macmillan D, Blamey RW, Ellis IO: High-throughput protein expression analysis using tissue microarray technology of a large well-characterised series identifies biologically distinct classes of breast cancer confirming recent CDNA expression analyses. Int J Cancer 2005, 116:340-350.

48. Abd El-Rehim DM, Pinder SE, Paish CE, Bell J, Blamey RW, Robertson JF, Nicholson RI, Ellis IO: Expression of luminal and basal cytokeratins in human breast carcinoma. J Pathol 2004, 203:661-671.

49. Brenton JD, Carey LA, Ahmed AA, Caldas C: Molecular classification and molecular forecasting of breast cancer: ready for clinical application? J Clin Oncol 2005, 23:7350-7360.

50. Rijn $M$ van de, Perou $C M$, Tibshirani $R$, Haas $P$, Kallioniemi $O$, Kononen J, Torhorst J, Sauter G, Zuber M, Kochli OR, Mross F, Dieterich H, Seitz R, Ross D, Botstein D, Brown P: Expression of cytokeratins 17 and 5 identifies a group of breast carcinomas with poor clinical outcome. Am J Pathol 2002, 161:1991-1996.

51. Tamimi RM, Baer HJ, Marotti J, Galan M, Galaburda L, Fu Y, Deitz AC, Connolly JL, Schnitt SJ, Colditz GA, Collins LC: Comparison of molecular phenotypes of ductal carcinoma in situ and invasive breast cancer. Breast Cancer Res 2008, 10:R67.

52. Wolff AC, Hammond ME, Schwartz JN, Hagerty KL, Allred DC, Cote RJ, Dowsett M, Fitzgibbons PL, Hanna WM, Langer A, McShane LM, Paik S, Pegram MD, Perez EA, Press MF, Rhodes A, Sturgeon C, Taube SE, Tubbs R, Vance GH, van de Vijver M, Wheeler TM, Hayes DF, American Society of Clinical Oncology, College of American Pathologists: American Society of Clinical Oncology/College of American Pathologists guideline recommendations for human epidermal growth factor receptor 2 testing in breast cancer. J Clin Oncol 2007, 25:118-145.

53. Begg CB, Zhang ZF: Statistical analysis of molecular epidemiology studies employing case-series. Cancer Epidemiol Biomarkers Prev 1994, 3:173-175. 